\title{
Israel-Palestine: The pedagogical challenge
}

\author{
Donald Grayston \\ Simon Fraser University \\ donald_grayston@sfu.ca \\ Dave Chang \\ University of British Columbia \\ dchang_accord@yahoo.ca
}

\begin{abstract}
The Israeli-Palestinian conflict began in a critical sense in 1948 and continues to this day. An understanding of this continuing dispute requires knowledge of its historical, political, religious, demographic, emotional and geopolitical dimensions, and of the way anti-semitism figures in how people engage in discussions of the Middle-East. After sketching out these realities, we consider how disagreement over the framing of the past generates disagreement over visions of the future. Drawing on the work of Jakob Feldt and Ilan Gur-ze'ev, among others, we highlight the challenges posed to educators in regard to how each of the two major narratives, Israeli and Palestinian, compete with the Other's account of their shared and fractured history. Using an incident involving the British Columbia Ministry of Education as a reference point, we explore the way special interest groups engage with the realm of public education, as well as the challenge of deconstructing conflicting historical interpretations. The paper suggests some pedagogical approaches for moving beyond the contesting of histories and for the development of better-grounded student involvement with this complex issue.
\end{abstract}

\section{The Incident}

News item: The Vancouver Sun, June 25, 2009

Controversial exam question wiped from education ministry's website, by Janet Steffenhagen

The Canadian Jewish Congress (CJC) is applauding B.C.'s new education minister for her swift action is pulling from her ministry's website a controversial question about the MiddleEast that was part of a practice test for students preparing for provincial exams.

The article expresses the satisfaction of the Canadian Jewish Congress (CJC) at Minister Margaret MacDiarmid's prompt action, and adds that the Congress would request a meeting with her to discuss the issue further. (In the course of writing this article, we requested an interview with the minister. However, at the time of its submission, no reply had been received. We did receive a response from one of her communications staff, but were not provided with any information, which might change what we have written. She was replaced as Minister of Education in November 2010).

Cultural and Pedagogical Inquiry, 2010, 2 (2), Special Issue, pp.19-32

ISSN 1916-3460 @ 2011 University of Alberta

http://ejournals.library.ualberta.ca/index.php/cpi/index 
The question asked students to identify the people-group referred to in this statement.

They have been fighting to regain a homeland since they were driven out in 1948. Some have lived their entire lives in refugee camps. Forty years later, Israel still refuses to recognize heir right to exist as a nation.

Students were asked to indicate whether the reference was to Jews, Iranians, Egyptians or Palestinians. An unnamed Vancouver student who "spotted" the question was "outraged" and contacted the Congress. CJC Pacific regional director Romy Ritter is quoted as saying that all three sentences in the question are historically inaccurate: "It's a one-sided view," she stated. In requesting a meeting with the minister, the article concludes, the Congress wishes to emphasize the need for fairness and balance in the curriculum.

And there it is- the pedagogical challenge of interpreting to high school students with fairness and balance the realities of the Israeli-Palestinian conflict, which has now been going on, in one form or another, since 1948. A similar action by her counterpart in Manitoba in June 2010 reinforces our sense of the importance of her decision (Sources News Release, 2010).

The purpose of this article is, finally- but only after exploring the historical, geographical, religious, political, emotional and geopolitical dimensions of the conflict- to offer some pedagogical perspectives, both theoretical and concrete, on how to present and interpret this situation to high-school students in a fair and balanced way that does justice both to its complexity and its simplicity.

We begin by sketching the background to the conflict, then by reflecting on the 2009 incident described above, and finally by exploring some pedagogical possibilities for approaching the conflict. In doing so, we make our own point of view clear, and invite our readers to respond from their own points of view. Our own point of view, then, in sum: justice for the Palestinians, security for Israel, peace in the Middle-East, and thereby greater stability for the entire world.

\section{The Background}

In sketching out the background to the conflict, we have begun with its simplicity. Both Israelis and Palestinians are suffering: the Israelis from fear, shame, guilt and frustration; the Palestinians from humiliation, frustration, dispossession, and the daily brutalities which come with occupation. Both populations regularly state their desire for justice and peace, but there is no agreement either within the Israeli population or the Palestinian population, let alone between them, as to how justice is to be done and peace achieved. We acknowledge that what we characterize here as simplicity, will be regarded by many on both sides as simplistic rather than simple.

The complexity manifests itself in the multi-dimensionality of the conflict and in its temporal length. A full historical enquiry takes us back beyond the foundation of the State of Israel and the concomitant expulsion and dispossession of 750,000 Palestinians (Pappé, 2006), to 
the guilty response of the "Christian" west to the revelation of the Holocaust. It then goes back to the promises made to both Arabs and Jews by the United Kingdom in the course of World War I; to the beginnings of the Zionist movement and its envisioning of the creation of a Jewish state in the late $19^{\text {th }}$ and early $20^{\text {th }}$ centuries; and to the relative entente between Jews and Arabs under Ottoman rule and in Muslim societies in general. Behind this stretches the long sad history of Christian anti-Judaism, beginning in the fourth century of our era. Beyond this we find the actively-remembered glory of the Davidic kingdom with its capital in Jerusalem (c. 1033-1000 $\mathrm{BCE}$ ); and ultimately we return to the patriarch Abraham (c. $1800 \mathrm{BCE}$ ), to whom, according to the biblical record (cf. Genesis 17), God promised the land then called Canaan, a territory known ever since as the Promised Land.

It is ironic that a territory with so much history should have so little geography. But within its limited land area, there are four components: Israel proper, that is, Israel within the borders delineated by the UN resolutions which created it in 1948, to which is currently attached the occupied Syrian territory of the Golan Heights; the West Bank, the larger Palestinian homeland, now also increasingly the location of illegal Israeli-built "settlements" (towns and cities, in fact) housing at the present time some half a million "settlers"; the Gaza Strip, bounded by the Mediterranean, the West Bank and Egypt, and inhabited by 1.5 million Palestinians who are not permitted to leave it; and the contested holy city of Jerusalem-sacred to Jews, Christians and Muslims, designated by the UN in 1947 as an international zone, regarded by Zionists as the eternal and indivisible capital of Israel, and seen by Palestinians as the future capital of an independent Palestinian state. To this geographic complexity we must also add demographic complexity. Presently, the Jewish citizens of Israel proper are in a majority; but if current demographic trends continue, the Arab-Palestinian citizens of Israel will be a majority within a generation.

The mixture of religious groups found within its boundaries further complicates the history of this contested land. Probably the greater part of the Israeli population, which is ethnically Jewish, is not religiously Jewish. Zionism was at its foundation an essentially secular and socialist enterprise, which garnered little support from religiously-observant Jews; and the majority of Israeli Jews continue the tradition of secularity, if no longer of socialism. The population also includes, however, politically influential numbers of Orthodox Jews, and, critical to our understanding of the situation, a smaller but intensely-committed cohort of ultranationalist Jews, who wish to see the boundaries of what they call Eretz Yisrael made coterminous with the putative boundaries of the kingdom of David (roughly present-day Israel and Palestine, with parts of Lebanon and Jordan). The larger part of the Palestinian population is Muslim, a population which is divided between moderate Sunni Muslims (who currently have political authority in the West Bank) and a smaller number of Islamist Muslims, also Sunni (who currently have political authority in Gaza). A decade ago, some $20 \%$ of the Palestinian population was Christian; but because of the emigration of Palestinian Christians to the "Christian" west, that proportion has been reduced as of 2010 to some $5 \%$.

Politically, the situation is equally complex. At the time of writing, Israel is ruled by a coalition in which the largest party is Likud, led by Prime Minister Benjamin Netanyahu, and includes Labor, which has often formed previous governments, and Shas, an Orthodox religious party, which often holds the parliamentary balance of power. In the West Bank, Fatah controls 
the Palestinian Authority, originally the party of Yasser Arafat, whereas Gaza is controlled by Hamas, an Islamist party with which Israel refuses to talk. The political loyalty of Palestinians is divided between Fatah and Hamas, and talks between them, mediated by Egypt, have so far failed to produce a workable plan for political unity.

We conclude this background sketch with reference to what is perhaps the most difficult dimension of all, the emotional. Both cultures are passionate ones, given to expressing their emotional attachment to their homelands to a degree unfamiliar to Canadians. This emotion reaches a climax when the subject of discussion is Jerusalem. Israeli rhetoric refers to Jerusalem as Israel's "eternal and indivisible" capital; and the intensity of Israeli feelings are captured memorably in the song "Yerushalayim Shel Zahav" ("Jerusalem of gold"), an anthem which celebrates the "reunification" of Jerusalem by Israeli forces in the Six-Day War of 1967. Palestinian Muslims and Christians express their yearnings through the name Al-Quds, "the Holy City," and through the devotion expressed by Muslims at the Dome of the Rock (a mosque built on the site of the ancient Jewish temples) and by Christians at the pilgrimage sites in the old city (Jerusalem Old City Initiative, 2010). On another emotional score, that of pathology, many observers regard both the Israeli and Palestinian populations as suffering from Post-Traumatic Stress Disorder (Shifrin, 2010; Hart, 2010). Thus we have two populations struggling with each other, both traumatized after more than six decades of conflict.

\section{The Geopolitical Reality}

Geopolitically, in our view, the Israeli-Palestinian conflict is one of the three most dangerous situations on the globe, together with the Indian-Pakistani rivalry and North Korea, with nuclear weapons being possessed by all three. Israel refuses either to confirm or deny that it possesses nuclear weapons; but it is an open secret that it holds some 200 nuclear weapons, which it could use, for example, to attack Iran. Of these three, the Israeli-Palestinian conflict is, in our view, the most dangerous, because it is the most volatile, and because it is enmeshed with Israel's relationship with the United States, for good and/or ill Israel's most significant international link (Mitchner \& Tuffs, 2003). They are connected by the perception that Israel (for the Jewish and Christian West) is the historic "holy land" of the East, and the United States is the "holy land" of the West. We mean by this that many Jewish Israelis and most Americans see their own countries as sacred, meaning that an attack - even a verbal attack - is experienced as outrage and sacrilege, not simply as assault. This is the mythic underpinning of the American response to the events of 9/11 which has been described in the work of Robert N. Bellah, who coined the term "American civil religion," meaning the integration of nationalism and religiosity (Bellah, 1967; "Civil religion," 2010), as well as in the work of sociologists and religious-studies scholars who have studied what they identify as American exceptionalism (Lipset, 1997; "American exceptionalism," 2010). The attack on the Twin Towers and the Pentagon, symbols of the economic and military might of the United States, constituted for many Americans an act of sacrilege far more than a military or criminal act, comparable perhaps to the dropping of a bomb on St. Peter's in Rome or on the Kaaba in Mecca. Had such an attack occurred in Canada, for example, which does not see itself as a sacred nation, it would have been experienced as military assault and crime, but not as sacrilege. This is because Canadian historical selfunderstanding has followed an increasingly secular trajectory, towards which we have been moved in part by our general (though not total) dismay at some of the expressions of civil 
religiosity during the administration of George W. Bush. Home to as many Jews as there are in Israel, the United States sends billions of dollars a year to Israel for military purposes, far more than it gives in aid to any other country, something now being questioned by many Americans. A recent address, for example, by Ambassador Charles Freeman at the Nixon Center, asks the question: is Israel an asset or a liability to the United States? (Freeman, 2010; Mitchner \& Tuffs, 2003). Meanwhile, the American Israel Public Affairs Committee (AIPAC) solicits support for Israel, and responds aggressively to any word or action from the US administration, which would suggest criticism of Israeli government policies or a weakening of support for Israel's actions. It is generally agreed that only the United States has the political and economic clout with Israel to compel it to end the occupation; and there is serious frustration among Palestinians and around the globe that the United States has not used that clout to compel an end to a situation which has kept Palestinians in misery and Israel in fear since 1948. The fact that Israel and the United States have, since the time of the administration of George W. Bush, been actively conferring about the possibility of a nuclear attack on Iran brings this relationship to its most critical focus. In early September 2010, direct talks without preconditions between Israel and the Palestinian Authority (but excluding Hamas) began in Washington, DC, brokered by President Barack Obama, and with the very ambitious goal of concluding a pact on all outstanding issues within a year. As of December, the talks were stalled over the issue of settlements: the Israelis continue to build them on Palestinian territory; the Palestinians refuse to return to the table until building ceases (Jackson 2010; Koring, 2010).

One of the official textbooks used in British Columbia for History 12 is Global Forces of the Twentieth Century, $3^{\text {rd }}$ edition (Mitchner \& Tuffs, 2003). Our sketching of this background to the Israeli-Palestinian conflict is in basic factual, though not always interpretative, accord with the account given there of its historical, geographical and political dimensions (Mitchner \& Tuffs, 2003). That account, however, does not deal with the religious and emotional dimensions, which we have summarized. In regard to the geopolitical dimension, it notes the American interest and involvement (Mitchner \& Tuffs, 2003), but does not expand on it or frame it as we have. Much of course has happened in the Middle East since the book was published in 2003, and until a revision of the text or the adoption of a newer one, teachers of History 12 will need to acquaint themselves thoroughly with subsequent events in the continuing saga of the conflict.

\section{The Issue of Anti-Semitism}

One further matter that needs to be clarified in any discussion of the pedagogical challenges of this issue is that of anti-semitism. In a number of recent instances, of which the subject of our case study is one, major Jewish organizations such as the CJC or B'nai Brith have objected to what others and we would simply see as criticism of the policies of the government of Israel on the ground that such a critique is implicitly anti-semitic. This is a point of view, which we do not accept. In our view, no government, including our own, is beyond criticism either from its own citizens or the citizens of other countries. We grant that the history of Christian anti-Judaism and anti-semitism complicates the responses of many people, Jewish and/or Israeli and otherwise, to the instances to which we refer. However, we have also come to a particular historical moment, the end of what Jewish theologian Marc Ellis calls the time of the "ecumenical deal" - more accurately an interfaith or intercultural "deal" (Ellis, 2009). The terms of the deal, which received major impetus from the publication of Elie Wiesel's (1958) powerful 
book, Night, were that Jews would not remind Christians and others of their responsibility for the Holocaust if they refrained from criticism of the State of Israel, the essential post-Holocaust representation of the Jewish people. However, the rise in public awareness of the suffering of the Palestinians and of Israel's concomitant need for security has led to the abrogation of this always-unofficial "ecumenical deal." At such a moment, it is understandable that there will be occasions of tension or misunderstanding of the difference between anti-semitism (a social evil, which must always be opposed) and criticism of the policies of the government of Israel, an entirely legitimate undertaking (Grayston, 2010).

\section{History as Conflict}

Given the multi-dimensionality of the Israeli-Palestinian conflict, which sees the ongoing clash of geographical, religious, demographic and political forces, the CJC's intervention in the History 12 exam incident reminds us that debates over historical representation are a part of the ongoing struggle between Israelis and Palestinians, and adds a further element of complexity to a conflict that many consider intractable (Kupermintz \& Salomon, 2005). Here we define history as the collective memory of past experiences, which, according to Saloman and Nevo (2001), include "traumatic memories of pain, humiliation, conquest, slavery, discrimination and the like, that fuel mistrust, animosity and conflict with another group" (p. 67). Both the Israelis and the Palestinians point to notable moments of trauma in their respective histories: Jews mourn the Holocaust, and the Palestinians the Nakba of 1948. Despite being "united in the strife that divides them," to borrow a phrase from T.S. Eliot, Israeli and Palestinian histories have unfortunately become mutually exclusive narratives, each one laying out competing claims over political legitimacy. These disputes over historical representation, therefore, must be seen as an extension of the larger struggle for land. Since history is the precondition of policy, political action cannot ignore the issues of justice implied by the two competing historical narratives. Disagreement over interpretations of the past is, therefore, disagreement over visions of the future. In addition, the CJC, by inserting its agenda into the realm of Canadian public education, demonstrates that these disputes are not confined to arenas of discourse in Israel/Palestine, and that Canada, as a member of the international community, has a vital role to play in the unfolding conflict in the Middle-East.

With respect to the history of the Israeli and Palestinian conflict, many theorists have provided useful insights about the utilization of historical narratives, carefully distinguishing historicity from history in the service of ideology (Gur-Ze'ev, 2001). Ilan Gu-Ze'ev (2001) notes in this regard that the Jewish memory of the Holocaust has been committed to the service of nation building:

The educational uses of the historical memory, its representation, distribution, and political realization are instrumentalized to negate the Palestinian identity, collective memory, rights, needs and hopes. Moreover, the evils inflicted on the Palestinians within the process of the Israeli nation-building project are veiled under the banner of morality of undoing the Jewish eternal victimhood as represented only recently in the Holocaust. (p. 256) 
The conflation of Israeli sovereignty and security with the pursuit of justice in the aftermath of the Holocaust is a historical construct that adheres closely to a Zionist agenda, with its ideological leanings toward an indivisible Jewish homeland (Hart, 2009). The Zionist telling of historical "facts" integrates the Holocaust into the larger visions of nationalism and therefore does not separate the actions of the state from the tragic experiences of its people. In the Zionist vision, the establishment of Israel redresses the horrors of the Holocaust, even if at the expense of Palestinians. On the other side of the ledger, the denial of the Holocaust by some Palestinians continues to stoke the fear and anger of many Jews. For example, in an official press release, Hamas has called the Holocaust "an alleged and invented story with no basis" (Washington Institute, 2000). The refusal of Hamas to recognize the Holocaust has also earned them the criticism of J Street, a progressive Jewish-American lobby committed to a peaceful resolution of the conflict through a two-state solution (Fingerhut, 2009). Many Jews regard the denial of the Holocaust as the negation of a defining moment in Jewish history that in effect renders void the 1947 UN resolution calling for a Jewish homeland and a Palestinian state. Holocaust denial is thus, for many Jews, tantamount to refusing Israel the right to exist. Feldt (2008) theorizes that with the Israelis, as with the Palestinians, continuous evisceration of the Other's history becomes "the mutual denial of the Other's legitimate existence" (p. 190).

History, in this antagonistic context is not a banal, civil and antiquarian interest ... it represents a deadly competition in which victory means the destruction of the Other .... In these kinds of histories the past is moralized, judged and indirectly re-created to destroy the Other as part of an existing existential conflict. (Feldt, 2008, p. 195)

The mutual denial of collective past experiences, Feldt (2008) further explains, amount to an assault on collective identity: "history is inevitable in as much as there are no identities without history; no Israelis or Palestinians" (p. 192). If the denial of history is the denial of each other's identity, then the removal of the History 12 question might be interpreted as an act of historical contest that deprives Palestinians of their historical identity.

Seen in this light, the CJC's demand that the question be removed, and Margaret MacDiarmid's subsequent capitulation, can be perceived by Palestinians as an act of historical denial and a repudiation of their rights to their land. In his open letter to the minister, Hanna Kawas, chairperson of the Canada Palestine Association (CPA), expressly refutes Romy Ritter's claim that all three sentences are "historically inaccurate" and decries the distortion of history represented by the question's removal (Kawas, 2009). One error is glaring, to be sure: whereas the Palestinians have been struggling for an independent state since 1948, the question allots only forty years to the Palestinian displacement, thus grossly under-representing the length of the Palestinian struggle. In our view, the facts evoked in the question, apart from the timeline gaffe, are in essence historically accurate, and consistent with the History 12 textbook, Global Forces in the $20^{\text {th }}$ Century. However, the historical veracity of the question is beside the point if the whistle-blowing student and the CJC objection to what they see as the biased orientation of the question, stemming from the words "driven out," with its underlying assumption of a Palestinian entitlement to territories, the claim to which is under vigorous debate. By removing an incendiary question, Margaret MacDiarmid's decision further escalates the continuing contest between historical narratives. Given that the historical perspectives held by both the pro-Israel lobby and the Palestinians serve distinct ideological objectives, the minister's criticism about the 
question being "one-sided" ignores the complexity and the contested nature of the issue. Since the Israeli-Palestinian narratives are still concurrently debated alongside the continuing political/military struggles in the region, scholars have yet to reach consensus on a version of Middle-East history that both Israelis and Palestinians can readily accept. As long as such a historical consensus remains elusive, "one-sidedness" will continue to be an unavoidable feature in discussions of Middle-East history. This makes the minister's actions doubly ironic, since by deeming the question too "one-sided" and removing it altogether, MacDiarmid has, in effect, made herself an arbiter of Middle-East history, whose judgment on the objectivity of the exam must be called into question. Indeed, who is to say which facts are "one-sided" when the conflict has not yet been settled and mutually exclusive versions of history currently define an acrimonious and polarized discourse?

Ultimately, the minister's capitulation does not concede to the demands of historicity but rather to the interests of a political lobby. Many lobbyists, of course, have made demands of the educational establishment. However, when lobby groups with specific political agendas exert pressure on a governing authority, the resultant changes in policy do not always promote open democratic dialogue, nor do they always affirm sound educational principles. Civic groups who intervene in the affairs of educational institutions are often compelled by political agendas rather than pedagogical concern. In this case, the removal of the Palestinian question forfeits an opportunity to include a greater range of perspectives that enrich and deepen educational practice. As a marked contrast to the political pressure from the CJC, we point to the efforts of the Gay and Lesbian Educators in British Columbia (GALE) in expanding the curriculum to include homosexual perspectives that challenge assumptions of hetero-normativity (Smith, 2004). By fighting the Surrey and Port Coquitlam school districts' decision to ban gay-lesbianpositive reading materials, activist teachers "put forth a counter discourse which problematized the normalized status of heterosexuality, arguing that lesbian and gay parents, their partners and their children should be represented in the school curriculum" (Smith, 2004, p. 132). The CJC and GALE, of course, have different agendas, but the two groups have in common their concern over issues of representation. They recognize that the presentation of specific sets of knowledge and the omission of others discursively inform judgments which become normalized as values. As such, GALE activists sought to broaden the curriculum by opening educational discussion to include gay and lesbian narratives in ways that strengthen liberal democratic dialogue within a pluralistic society. The CJC, on the other hand, attempts to limit the study of history by excluding narratives that run counter to its own script, thereby divesting the Middle-East discussion of its range of requisite voices and foreclosing opportunities for fair representation and democratic debate in education.

MacDiarmid's decision to remove the question was, therefore, in our view, an act of political expedience without educational merit. Her characterization of the "one-sided" nature of the question assumes that an objective and neutral perspective is readily available, even though scholars, politicians, and activists have yet to agree on a historical interpretation of events that is equitable and acceptable to both Israelis and Palestinians. Granted, while teachers may maintain a veneer of objectivity by teaching facts about the conflict, such as dates and geographical details, such methods impart only a superficial understanding of a deeply complex subject, and miss the opportunity to cultivate critical thinking and informed citizenship among students. While the Middle-East debate remains incendiary, the minister's action plays too readily into the 
politics of historical denial and sacrifices educational values in exchange for the approval of a lobby group. The study of such controversial subjects, we believe, must be grounded in sound pedagogical principles that brace educators against such political pressures.

\section{History as Problem}

The study of history is by nature controversial and often invidious, because historical narratives cannot easily be separated from political agendas and ideologies. Nowhere is this complexity more apparent than in the study of the Middle-East. Where controversy is unavoidable, it must then be skillfully employed as a resource. Rather than skirting contentious issues, educators and students stand to gain by delving deeply into debates that require consideration of diverse voices. To deprive students of such a valuable learning opportunity for fear of criticism constitutes a disservice to all learners. A critical understanding of history begins with asking students to consider contested historical narratives and to evaluate the legitimacy of divergent points of view. More importantly, as Feldt (2008) points out, students must be able "to point to history as part of the problem and to collective memory as education representing an ideology" (p. 202). In other words, students should see all historical narratives, including their own, as constructs which serve specific worldviews with their concomitant agendas. Only then will they be enabled to attend to the utilization of history and the way it is instrumentalized to achieve political goals.

The story of modern Zionism, for example, can be told in a variety of ways. First, Zionism may be seen as a European colonial movement, with superior organization and devastating military prowess, which, like other colonial movements, has inflicted indelible physical, psychological, cultural and political damage on the indigenous population (Docker, 2006). Alternatively, Zionism may also denote a "cosmopolitan, humanist, romantic reaction to European nationalism and ethnocentrism driven by hope and the longing for freedom" (Feldt, 2008, p. 200). Both versions are utilized in the service of distinct political ideologies. The ambiguity of the Zionist story and the multifarious ways it can be interpreted not only affords the opportunity for students to become critical of historical perspectives, it also offers a way to study how history is utilized as a rhetorical strategy in political debate. In other words, students are not only studying factual accounts of past events, they are also examining the way these accounts evolve as they are continuously deployed within the realm of political contestation. This exploration leads students to identify the ways in which historical knowledge is created, debated, revised, and in some cases, erased. This exploration breeds an appreciation of historical knowledge as tentative, fraught, and evolving as students consider issues of power and its effect on national identity and experience.

This engagement with history through the analytical deconstruction of conflicting historical accounts (that is, the politics of their creation) should go hand in hand with the ability to adjudicate between them. The former is too often neglected in favour of the latter. In this regard, Woelders (2010) has provided an effective pedagogical utilization of the Middle-East controversy by asking his students to evaluate the minister's decision to remove the question from the exam, and to consider whether the question was indeed "one-sided." Using historical accounts from a variety of sources, including revisionist accounts from Ilan Pappé and Benny Morris, Woelders (2010) posed the following question to his students: "Were the Palestinians 
deliberately "driven out" of their homeland by the Israelis during the 1948 Arab-Israeli war?" (p. 32). Some students decided that the histories are too polarized to arrive at a neutral judgment of the question; others thought the complexity of the history would be better addressed through an essay question. Woelders' assignment requires higher levels of thinking (synthesis, evaluation) and therefore trains the critical faculties that we value in an informed citizenry. To add to Woelders' activity, however, we would encourage students to apply their analytical skills in identifying the political parties involved in the question's removal and their respective interests. This would include a look at the CJC, the BC Ministry of Education and the CPA's roles in the Middle-East conflict, and how their interactions imply larger insights about the Israeli/Palestinian struggle. This inquiry takes students through a tour of Canadian foreign policy, the divergent voices within the Jewish community, the influence of political lobbies and the international repercussions of the conflict. After all, the ministerial incident should require more of students than merely judging the fairness of the minister's decision; it should help them recognize the ways in which a geopolitical conflict is played out across the world. Through looking at the specific interests of all players and the way they wield history as a tool, students are more likely to understand history as dynamic, evolving and lively.

\section{Peace Education}

That schools must aim to promote greater respect for human rights and strengthen commitment to social justice in the pursuit of peace is an ideal ensconced in the Universal Declaration of Human Rights (United Nations, 1948). In the aftermath of World War II, many educators around the world began to examine the nature of conflict and ways of preventing war. This movement can be loosely referred to as Peace Education, a broad educational philosophy rooted in the concern for fundamental human freedom, and the persistent attempt to reduce and eradicate all forms of violence, be they racial, cultural, political or systematic (Reardon, 1997). Peace education subsumes all studies of social justice and advocates not only the elimination of war but, more importantly, the creation of conditions for peace, without which the protection and celebration of human dignity will forever remain elusive. Studies of historical conflicts have all too often been limited to examinations of the causes of war. With regard to the Middle-East, the evaluation of two opposing historical interpretations, even if both sides were to be given equal time and attention, would neglect consideration of peaceful resolution. Because the study of historical causes of conflict tends to assign blame and politicize shared tragedies along sectarian lines, students are often left without tools with which to imagine a less violent future. This "disinterested" study of history betrays the immediate and real concern for human dignity in the interests of academic "fairness" and "objectivity." We believe that peace education, with its explicit aim of reducing violence and conflict, provides an appropriate lens through which Middle-Eastern studies should be conducted. Since history is a central dimension of the IsraeliPalestinian conflict, and no single interpretation of history is above contestation, "fairness" for both parties can only be experienced in the form of peaceful resolution. This is, in essence, a consequentialist view of education, which sees the end of conflict as the ultimate manifestation of justice, in the absence of which all lesser settlements, including the triumph of one historical interpretation over another, must stoke existing tensions.

The study of the Middle-East through critical analysis of the politics of historical

contestation should be further complemented by active participation in inter-group dialogues and 
simulations where students confront the dilemmas and moral ambiguities that the Middle-East conflict imposes. These activities and experiences, founded upon the principles of peace education, encourage students to move imaginatively beyond historical debate. Many educators in the Middle-East itself see schools as playing a vital role in dissolving the institutional and national antagonism that so embattle the region. For example, the Hand in Hand Center has, since 1997, established four schools within Israel with the goal of establishing peace between Arabs and Israelis through bilingual and multi-cultural education (Hand in Hand, 2010). Unlike the majority of schools in Israel, the Hand in Hand model of education brings Israeli and Palestinian staff and students together in learning "to live with difference, complexity, and even contradiction" (Hand in Hand, 2010). Furthermore, "pluralism, equality and democratic process are more than subjects - they are a way of life" (Hand in Hand, 2010). In Canada, similar programs have gained momentum. Peace It Together (PIT), for example, based in Vancouver, draws Palestinian, Israeli and Canadian teens together to produce films about the Middle-East conflict (Peace It Together, 2010). The teenagers spend two weeks together on a quiet island, far from distractions, where honest discussions about collective experiences culminate in the production of a series of short films, which are then screened at film festivals. The process of collaboration is emotional and intense; raw wounds of hurt and anger are exposed. However, as the teenagers traverse through their individual and collective suffering, new relationships and perspectives emerge. The resultant films are poignant and eloquent expressions of hope and humanity. Unlike the peace education movement in the Middle-East, Peace It Together calls on the involvement of Canadian teens, who broker dialogues, which highlight the shared humanity of all participants. This Canadian involvement signifies the role of the international community in mediating long-standing disputes. Whereas Israelis and Palestinians as national groups are so far unable to move beyond hostility, the influence of a third party is crucial to equitable and productive negotiations. Thus, as an exercise in peace education, the Canadian students are not distant and dispassionate observers, but rather active participants who help to defuse hostilities by opening doors of understanding and communication.

In peace education, the goal is not merely the development of knowledge of the subject, but rather a set of functional skills in achieving a specific goal. It is a pro-active education for peace rather than an education about peace. For the contesting parties, peace education encourages openness and acceptance of the Others' holding of their own perspectives as legitimate; as such, peace education offers an alternative to the denial of history that continuously aggravates conflict. In the Canadian context, peace education recruits Canadian students on the road to peace, helping them develop an intimate knowledge of the subject through active participation in the Israeli/Palestinian dialogue. This active involvement in intergroup encounters makes the curriculum more relevant because the direct engagement with Israelis and Palestinians becomes a living reference point for the otherwise theoretical studies of democracy, pluralism, human rights and conflict resolution. Moreover, this approach introduces the skills and responsibilities of international citizenship, building on experiences that can lead to greater global activism and interest in social justice.

Another tool for peace educators is PeaceMaker, an interactive computer game that allows the player to assume the role either of the Israeli Prime Minister, or that of the President of the Palestinian Authority. In order to meet the objective of the game, the player must use various military and diplomatic tools to achieve political goals even while negotiating many 
conflicting pressures. As the Israeli Prime Minister, the player must attend to the nation's security as well as the Palestinians' demands for greater autonomy and justice. As the President of the Palestinian Authority, the player must establish rapport with Israel while at the same time gathering the support of the international community for a comprehensive peace accord. The game begins with a violent incident, either a terrorist attack or a military incursion, and the player must respond with the goal of building a lasting peace agreement. A series of dilemmas arise as the game unfolds: to react to symptoms or address underlying causes; to secure shortterm political capital or to invest in long-term solutions. Because peace is the prescribed objective of the game, the player must experiment with and rehearse the skills and strategies required in the peace process, thus learning the topic through interaction with the simulated subject. The game highlights the many obstacles faced by the Israelis and Palestinians; those who have played the game become more eager to engage in discussions of the conflict, offering better-informed comments about the situation. Further, participants become acquainted with their own role as peacemakers, a position that implies active participation in the affairs of the world at large.

With its engaging format and educational premise, PeaceMaker can be effectively utilized to spur greater interest in the Middle-East while inviting young people to play a greater role in the peace process. Their participation would be a timely response to the Canadian government's marked shift toward a pro-Israel policy in the last few years. Indeed, the Harper government's stalwart support of Israel departs radically from Canada's long-standing role as conflict mediator, and signals a new type of Canadian involvement in the community of nations. This significant change in Canadian foreign policy raises new questions of power, interest and social justice for students of history. Through the process of critical analysis and inquiry, students can realize the ramifications of Canadian foreign policy, and in the process, locate their own position in relation to the Middle-East conflict.

\section{Conclusion}

The Israeli-Palestinian conflict is complex and multi-dimensional, compounded by historical, religious, political, cultural, and demographic factors. The mutual denial of the Other's history, by Palestinians and Israelis alike, is an extension of the geographical struggle for land too often used as a political device to further antagonize or attack the opposing party and act of rhetorical aggression, which escalates the suspicion and resentment that so plague MiddleEast discourse. Compelled by the CJC, Margaret MacDiarmid's decision to remove the Palestinian question from the sample History 12 exam inadvertently plays into this political contest. The minister's action is thus a political maneuver that serves the pro-Israel lobby rather than the public educational mandate. The removal of the question misses the opportunity for educators and students to discuss not only a variety of historical perspectives, but also how each perspective serves a distinct agenda and ideology. In a society where such governmental actions can be taken, we propose that in addition to a critical awareness of historical perspectives, students should also realize the politics of how perspectives are created and used in continuing conflicts. In addition to the ability to adjudicate between contesting historical narratives, students should be able to analyze and deconstruct the conflict itself and infer from this insights about the larger geopolitical struggle. Rooted in this principle, we believe Middle-East education can be further augmented by the principles of the peace education movement, with its 
attempts to promote dialogue and understanding among Israelis and Palestinians. Peace education in Canada would assign Canadian students an active role in the peace process, developing within them a sophisticated grasp of the Middle-East situation through direct involvement in inter-party dialogue (Peace It Together) or simulated games requiring reasoned judgment and skillful mediation (PeaceMaker). With such tools and initiatives in place, we look forward to more informed and better-grounded student participation in the Middle-East peace process as educators utilize these methods in their classrooms.

\section{References}

American exceptionalism. Retrieved from en.wikipedia.org/wiki/American_exceptionalism Bellah, R.N. (1967). Civil religion in America. Journal of the American Academy of Arts and Sciences, 96 (1), pp. 1-21. Retrieved from en.wikipedia.org/wiki/American_civil_religion

Docker, J. (2006). Review article cosmopolitan conversations: Settler societies, education and decolonization. Holy Land Studies: A Multidisciplinary Journal (Edinburgh University Press, 5(1), pp. 113-118.

Ellis, M. H. (2009). Judaism does not equal Israel. New York, NY: The New Press.

Feldt, J. (2008). History and peace education in Israel/Palestine: A critical discussion of the use of history in peace education. Rethinking History, 12(2), pp. 189-207.

Fingerhut, E. (2009). J Street blasts Hamas’ Holocaust denial. Retrieved from http://blogs.jta.org/politics/article/2009/09/01/1007583/j-street-blasts-hamas-holocaustdenial

Freeman, C. (2010). Israel: asset or liability? Retrieved from http://www.nixoncenter.org/index.cfm?action=showpage\&page=Freeman-Israel-Assetor-Liability

Grayston, D. (2010). Is criticism of Israel anti-semitic? Retrieved from http://www.vancouver.anglican.ca/portals/0/repository/01_2010 Topic proof2.pdf

Gur-Ze'ev, I. (2001). The Production of self and the destruction of the Other's memory and identity in Israeli/Palestinian education on the Holocaust/Nakbah. Studies in Philosophy \& Education, 20(3), pp. 255-266.

Hand in Hand. (2010). Hand in Hand School Model. Retrieved from http://www.handinhand12.org/index.cfm?fuseaction=content.display\&pageID=2

Hart, A. (2009). Zionism: The real enemy of the Jews. Atlanta, GA: Clarity Press.

Hart, A. (2010). Retrieved from http://www.alanhart.net/do-most-israelis-and-many-otherjews-need-to-feel-persecuted/?utm_source=feedburner\&utm_medium=email\&utm_cam paign=Feed:+AlanHart+(AlanHart+(Recent+Posts)

Jackson, F. K. (2010). Israel, Palestinians to resume direct talks with U.S. deadline of one year. Retrieved from http://www.bloomberg.com/news/2010-08-20/israel-palestinians-toresume-direct-talks-with-u-s-deadline-of-one-year.html

Jerusalem Old City Initiative. Retrieved from http://web2.uwindsor.ca/wsgcms/Projects/JerusalemInitiative/indexTpl.php

Kawas, H. (2009). Open letter to the minister of education. Retrieved from http://rebelyouthmagazine.blogspot.com/2009/07/open-letter-to-margaret-macdiarmid-bc.html

Koring, P. (2010). Israel, Palestinians agree to peace talks. Globe and Mail, August 21, A7. 
Kupermintz, H. \& Salomon, G. (2005). Lessons to be learned from research on peace education in the context of intractable conflict. Theory Into Practice, 44(4), pp. 293-302.

Lipset, S.M. (1997). American exceptionalism: A double-edged sword. New York: W. W. Norton.

Mitchner, E.A. \& Tuffs, R.J. (2003). Global forces of the twentieth century, $3^{\text {rd }}$ ed. Toronto, ON: Thomson Nelson.

Pappé, I. (2006). The ethnic cleansing of Palestine. Oxford: One World.

Peace It Together. (2010). Empowering youth to promote peace through dialogue, film-making and multimedia. Retrieved from http://www.peaceittogether.ca/

PeaceMaker. (2010). Retrieved from http://www.peacemakergame.com/game.php

Reardon, B. (1997). Human rights as education for peace. Retrieved from http://www.pdhre.org/book/reardon.html

Smith, M. (2004). Questioning heteronormativity: Lesbian and gay challenges to education practice in British Columbia, Canada. Social Movement Studies, 3(2), pp. 131-145.

Salomon, G. \& Nevo, B. (2001). The dilemmas of peace education in intractable conflicts. Palestine - Israel Journal of Politics, Economics \& Culture, 8(3), p. 64.

Shifrin, J. (2010). Presentation on behalf of Building Bridges. Vancouver, April 19.

Tolan, S. (2006). The lemon tree: An Arab, a Jew and the heart of the Middle East. New York, NY: Bloomsbury.

United Nations. (1948). United Nations Declaration of Human Rights - article 26. Retrieved from http://www.un.org/en/documents/udhr/index.shtml

Washington Institute. (2000). Palestinian holocaust denial. Retrieved from http://www.washingtoninstitute.org/templateC05.php?CID=1946

Wiesel, E. (1958). Night. New York, NY: Bantam Books.

Woelders, A. (2010). Debating the exam: The 1948 Palestinian exodus. Dimensions of Social Studies in B.C. Retrieved from http://bctf.ca/BCSSTA/members/newsletter/Dimensions_Summer_2010.pdf 